\title{
Treatment of non-motor symptoms in Parkinson's disease
}

\section{Anna Sauerbier ${ }^{1}$, Ilaria Cova ${ }^{2}$, Miguel Rosa-Grilo ${ }^{1}$, Raquel N Taddei ${ }^{1}$, Laurie K Mischley $^{3}$, K Ray Chaudhuri ${ }^{1}$}

${ }^{1}$ King's College London and King's College Hospital, London, UK

${ }^{2}$ Center for Research and Treatment on Cognitive Dysfunctions, Institute of Clinical Neurology, Department of Clinical Sciences, x2018; Luigi Sacco' Hospital, University of Milan, Milan, Italy.

${ }^{3}$ Bastyr University Research Institute, 14500 Juanita Drive NE, Kenmore, WA 98133, USA; UW Graduate Program in Nutritional Sciences, 305 Raitt Hall, P.O. Box 353410, Seattle, WA 98195, USA; Department of Radiology, University of Washington (UW), P.O. Box 357115, 1959 NE, Pacific Seattle, WA 98195, USA.

Key words: Non-motor symptoms, treatment, Parkinson's disease

\section{Address Correspondence to:}

Dr Anna Sauerbier

Movement Disorders and BRC Fellow to Professor K Ray Chaudhuri

National Parkinson Foundation International Centre of Excellence

Kings College Hospital NHS Foundation Trust

EUROPAR offices, 2nd floor, On-Call Building

Denmark Hill

London SE5 9RS

Ph: +44 2032997189

Word count: 4052 words; Title count: 5 


\begin{abstract}
Non-motor symptoms (NMS) are integral to Parkinson's disease (PD) and the management can often be challenging. In spite of the growing evidence that NMS have a key impact on the quality of life of patients and caregivers, most clinical trials still focus on motor symptoms as primary outcomes. As a consequence strong evidence based treatment recommendations for NMS occurring in PD are spare. In this chapter we describe the current data addressing the treatment of major NMS such as sleep, cognitive and autonomic dysfunction, depression and anxiety.
\end{abstract}

\title{
Introduction
}

Non-motor symptoms (NMS) are integral to the course of Parkinson's disease (PD) (Sauerbier and Ray Chaudhuri, 2014) and being one of the key factors for the quality of life of both patients and caregivers, NMS play a major role in the management of this neurodegenerative condition (Martinez-Martin, 2014). Since 2006, objective measurements of NMS with validated tools (questionnaires and scales) have been developed, which are now in widespread use in standard clinical care and clinical trials. The two main NMS tools are the patient completed NMS Questionnaire (NMS Quest) and health-professional completed NMS Scale (NMSS) (Chaudhuri et al., 2006b, Chaudhuri et al., 2007, Chaudhuri et al., 2006a). In addition, NMS can also be measured, although in a limited fashion, by the NMS section of the Movement Disorders Society- Unified Parkinson' disease rating scale (MDS-UPDRS) (Goetz et al., 2008). Figure 1 summarizes a proposed pathway that might help to assess and manage NMS in clinical practice.

In this chapter we review published clinical trials addressing the treatment of NMS in PD with a particular focus on trials using the NMS Quest and NMSS, which have the 
most widely published clinometric data. Major NMS, including sleep, cognitive and autonomic dysfunction as well as depression and anxiety, will be described in detail.

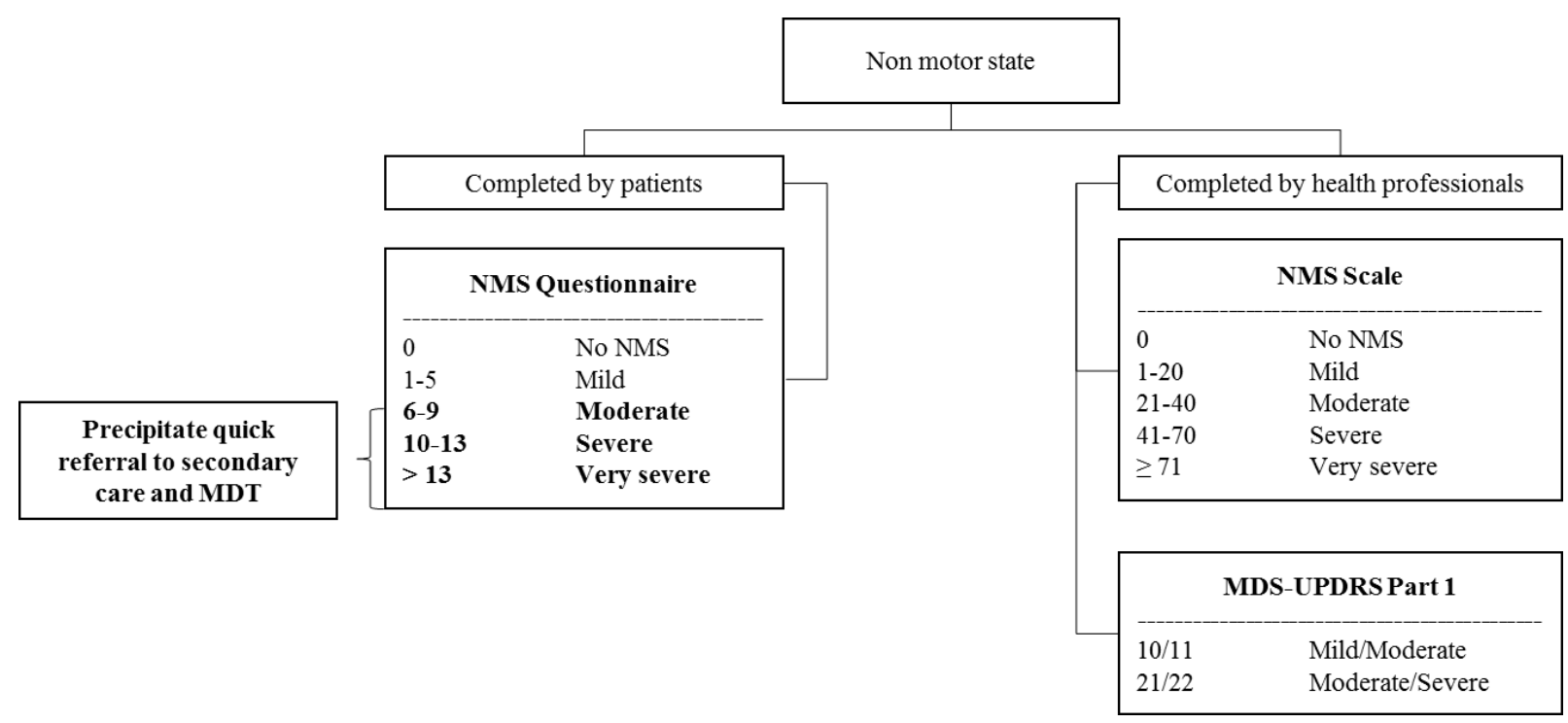

Figure 1: Proposed pathway to assess NMS holistic in clinical practice and consider further management

MDT $=$ Multi-disciplinary-team; NMS = Non-motor symptoms; MDS-UPDRS = Movement Disorders Society- Unified Parkinson's disease rating scale (Ray Chaudhuri et al, 2015; Sauerbier et al, 2016)

\section{Sleep}

Sleep disturbances are common in PD and consist mainly of night-time sleep difficulties such as insomnia, rapid eye movement (REM) sleep behavior disorder (RBD), restless legs syndrome (RLS), periodic limb movement disorder (PLM), and sleep disordered breathing, but also of excessive daytime sleepiness (EDS) and early morning 'off' (Chahine et al., 2016). In clinical practice, apart from the NMS Quest and NMSS, more specific tools, such as the Parkinson's disease Sleep Scale version 1 and 2 (PDSS and PDSS-2) (Chaudhuri et al., 2007, Trenkwalder et al., 2011b) and the 
Epworth Sleepiness Scale (ESS) (Johns, 1991, Hagell and Broman, 2007), are available to investigate sleep disturbances in the bedside.

Despite the overwhelming importance, only few randomized controlled trials and high quality open-label studies have approached the management of sleep disturbance in PD (Chahine et al., 2016, Schrag et al., 2015, Rodrigues et al., 2016).

As first line interventions, general sleep hygiene recommendations cannot be overemphasized, and the potential effects of dopaminergic therapy on sleep investigated. It has been recognized that some sleep symptoms can be worsened by dopaminergic therapy, as seen with EDS for example, possibly due to the action of dopamine D3 agonists, as has been suggested in the proposed Park Sleep subtype (Sauerbier et al., 2016).

On the other hand, sleep fragmentation can be partly explained by night-time motor fluctuations. and RLS. Continuous drug delivery, as well as controlled-release formulations of levodopa or dopamine agonists, transdermal delivery of rotigotine, and addition of inhibitors of catechol-O-methyltransferase or monoamine oxidase-B can be effective improving nocturnal motor disability, fluctuation as well as early morning 'off'. Aforesaid observations have been previously reported with cabergoline (Romigi et al., 2006, Marco et al., 2002). A recent open-label, multicenter study has shown a positive effect of rasagiline as mono- or add-on therapy on sleep disturbances as assessed by PDSS (Panisset et al., 2016). Additionally, rotigotine transdermal patches have shown to ameliorate sleep dysfunction in PD in randomized trials. The multicenter, randomized, double-blind, placebo-controlled 'RECOVER' trial investigated the effect of the rotigotine transdermal patch on sleep dysfunction and showed a significant improvement in nocturnal sleep disturbances as assessed by PDSS-2 and NMSS (Trenkwalder et al., 2011a). These results are in line with 
findings of open-label studies and a randomized trial using subjective clinical scales and objective recordings, including polysomnography (Pagonabarraga et al., 2015, Calandra-Buonaura et al., 2016, Pierantozzi et al., 2016). Furthermore, the 'RECOVER' study reported a low incidence of EDS as an adverse event (Trenkwalder et al., 2011a). It has been hypothesized that this might be at least partly explained by the fact that rotigotine does not share the high affinity D3 receptor profile of other dopamine agonists (Sauerbier et al., 2016, Chaudhuri and Sauerbier, 2016).

Beneficial effects have been observed with PD advanced therapies in open-label studies as well. Results from a surveillance-based study on apomorphine showed a significant improvement in the domain of sleep/fatigue of NMSS at follow up, of particular importance in individual items assessing fatigue, sleep-onset insomnia and RLS (Martinez-Martin et al., 2011). The open-label, prospective, observational, multicenter 'Euroinf' study compared patients on apomorphine infusion to patients on intrajejunal levodopa infusion (IJLI) which demonstrated a significantly higher improvement in NMSS sleep domain for those on IJLI (Martinez-Martin et al., 2015). Zibetti et al also noted improvement in subjective sleep quality and EDS as assessed by PDSS-2 and ESS in patients treated with IJLI (Zibetti et al., 2013). Significant improvement has been described after bilateral subthalamic stimulation measured by NMSS sleep domain and PDSS (Dafsari et al., 2016). Furthermore, similar results have been achieved after microsubthalamotomy in a small sample of 15 patients (Merlino et al., 2014). However, a recent systematic review on deep brain stimulation (DBS) and sleep-wake functions in PD has summarized that the current literature is conflicting and more work is needed in this field (Eugster et al., 2016). 
When further pharmacological intervention is warranted to treat insomnia, antidepressants (including tricyclics, trazodone, agomelatine), non-benzodiazepine hypnotics (including eszopiclone) as well as melatonin ( $5 \mathrm{mg}$ /day) can be tried (Rios Romenets et al., 2013, Seppi et al., 2011, Dowling et al., 2005). Doxepin, a tricyclic antidepressant with selective histaminergic antagonistic action, has been reported to be effective at low dosages (10 mg/day nocte) (Rios Romenets et al., 2013). Additionally, it is important to consider the sleep environment and ensure that RBD sleep-related injury is prevented (Chahine et al., 2016). Melatonin and clonazepam are prescribed routinely to control RBD, with the former showing a more favorable adverse event profile in patients with concomitant sleep disordered breathing (Aurora et al., 2010). A randomized, double-blind, placebo-controlled trial investigated the effects of rivastigmine transdermal patch $(4.6 \mathrm{mg} /$ day $)$ in a small sample of PD patients with severe RBD ( $>5$ episodes/week) refractory to clonazepam ( $2 \mathrm{mg} /$ day) and melatonin ( $5 \mathrm{mg} /$ day). Rivastigmine was found to significantly decrease the number of RBD episodes at 3-week follow up (Di Giacopo et al., 2012).

RLS in PD is currently not yet fully understood and there are currently no randomized controlled trials addressing the different therapies to improve RLS specifically occurring in PD. Generally, iron deficiency should be excluded as a cause of RLS in PD. Studies investigating the effect of DBS have reported conflicting findings. (Chahine et al., 2016).

EDS should be primarily addressed by reducing potentially causative medications. Combined analysis of 3 randomized, double-blind, placebo-controlled trials support the evidence that modafinil (100-200 mg/day) taken in the morning improves EDS in PD patients (Rodrigues et al., 2016). Other stimulants such as caffeine and methylphenidate have been investigated as well, however, these therapies remain 
investigational (Postuma et al., 2012, Chahine et al., 2016). Sodium oxybate at nighttime has also been suggested for the treatment of EDS (with caution because of addictive potential) and further studies are currently investigating this effect (Ondo et al., 2008). One study has shown that when continuous positive airway pressure (CPAP) is used to treat sleep apnea, it has an additional positive effect on EDS as well (Neikrug et al., 2014).

Apart from pharmacological therapies, some non-pharmacological interventions have observed interesting positive results, such as a multidisciplinary intensive rehabilitation treatment (Frazzitta et al., 2015) and bright light therapy (Rutten et al., 2012). However, such treatments are not readily available worldwide.

In conclusion, management of sleep dysfunction is complex and needs accurate diagnosis of the specific type of disturbance, which can be achieved with clinical tools such as the PDSS. Therapy should then be tailored according to specific issues such; as early morning 'off', nocturnal motor symptoms, sleep fragmentation, RLS and RBD. Apart from the few but increasing number of studies addressing sleep disturbances in $\mathrm{PD}$, strong recommendations cannot be made at this point.

\section{Cognition}

Cognitive impairment is a common NMS in PD (Broeders et al., 2013). Initial deficits presenting as mild cognitive impairment (MCI) can be detected in $15 \%$ of patients at the time of diagnosis (Aarsland and Kramberger, 2015). Those may remain stable or progress to PD dementia (PDD) over time. Only a few systematic studies are currently available which addressed the treatment of cognitive impairment specifically in PD. In a recent systematic review physical activity was shown to 
positively impact cognition in PD (Cusso et al., 2016). The effect of drug therapy on MCI is currently controversial (Strohle et al., 2015). Arecent study highlighted that application of anodal transcranial direct current stimulation could improve cognitive abilities in MCI PD (Manenti et al., 2016).

Treatment of PDD in clinical practice can involve the use of cholinergic agents. Rivastigmine has been shown to be efficacious in large, randomized placebo controlled trials (Seppi et al., 2011). On the other hand, open-label and randomized controlled studies also suggested that donepezil can improve cognition in PD, but the results are inconclusive and as such no general recommendations could be made. (Cooney et al, 2016). Galantamine has only been evaluated for PDD in open label studies and evidence is currently insufficient to recommend Galantamine for the treatment of PDD (Seppi et al., 2011). A recent systematic meta-analysis suggested that memantine, a low-affinity antagonist to glutamate NMDA receptors, possibly shows a slight improvement in global impression of cognitive dysfunctions in PD (Wang et al., 2015) .

Moreover, a small, open label, pilot study of atomoxetine for cognitive impairment found an improvement in executive functions measures (Marsh et al., 2009). In conclusion, cognitive dysfunction may occur in PD even at early stages, now recognized as Park Cognitive subtype (Sauerbier et al., 2016). Cognitive dysfunction is one of the key problems in advanced PD and reasonable evidence base exists with cholinergic agents in PD. However, further research needs to be conducted.

\section{Depressive symptoms and anxiety}


The prevalence of depression and anxiety disorders in PD varies considerably across different settings and the screening tools used. Recently published systematic reviews estimate a prevalence for both, major and minor depression, and any anxiety disorder, to be around 30\% (Goodarzi et al., 2016, Broen et al., 2016).

Behavioral and psychosocial interventions in PD patients have been shown to have a beneficial effect particularly during the acute management of depression and anxiety, while longer term effects are still unclear (Yang et al., 2012). In this context, cognitive behavioral therapy (CBT), with some studies looking at telephoneadministered CBT, has shown promising results (Armento et al., 2012, BomasangLayno et al., 2015). Bright light therapy has been suggested as beneficial for depressive symptoms in PD, possibly through restoring the circadian rhythm which maybe involved in the development of depressive symptoms (Rutten et al., 2012). A recent systematic review has highlighted the potential positive impact of physical activity on NMS such as depression, however further studies are needed to confirm this (Cusso et al., 2016). The first treatment with electroconvulsive therapy (ECT) for psychiatric and neurological disorders goes back to 1947 (Moellentine et al., 1998, Narang et al., 2015). The usefulness of ECT in PD has been recently outlined with a positive effect being described on depressive symptoms, however more prospective, controlled studies are needed in this field to evaluate if ECT should be considered earlier (Borisovskaya et al., 2016).

Regarding pharmacological interventions, it is important to establish if depressive symptoms and anxiety are related to non-motor fluctuations in which case adjustment of dopaminergic medication should be considered. 
Furthermore, serotonin-norepinephrine reuptake inhibitors (SNRIs) such as

mirtazapine and venlafaxine as well as serotonin selective reuptake inhibitors (SSRIs) such as fluoxetine, sertraline, citalopram and paroxetine are among the commonly used treatments for depressive symptoms and anxiety in PD. Moreover, tricyclic antidepressants (TCAs) including amitriptyline and nortriptyline are commonly used in clinical practice as well. Even though the published literature is conflicting, in general SSRIs remain the first treatment of choice (Pena et al., 2016).

There is now also good evidence that several dopaminergic drugs are useful to treat depressive symptoms in PD. Pramipexole, a dopamine agonist, has been shown to be efficacious for the treatment of depressive symptoms in PD (Barone et al., 2010). The 'RECOVER' study showed an improvement in depressive symptoms assessed by the Beck Depression Inventory (BDI-II) and NMSS with rotigotine (Trenkwalder et al., 2011a). Furthermore, a prospective open-label multicenter study investigating the effect of ropinirole over 6-months, showed a significant improvement in depressive symptoms and anxiety measured by the Hamilton Anxiety Scale (HAM-A) and Montgomery-Asberg Depression Rating Scale (MADRS) in patients with motor fluctuations (Rektorova et al., 2008). Other studies have demonstrated similar results, describing considerable improvements in depressive symptoms with ropinirole (Buchwald et al., 2007). Published data of the effect of rasagiline on depressive symptoms in PD patients is controversial. A post-hoc analysis of the data from the ADAGIO study in drug naïve PD patients showed that the add-on therapy with rasagiline (1 or $2 \mathrm{mg}$ per day) had a beneficial effect on depression in PD patients on antidepressive medication (Smith et al., 2015). However, other studies do not confirm this positive finding (Barone et al., 2015). A multicenter, open-label, prospective, 
observational 6-month study comparing the effect of apomorphine to IJLI on NMS, motor symptoms and quality of life indicated that both advanced therapies improve the NMSS domain mood/apathy with a superiority observed with apomorphine (Martinez-Martin et al., 2015).

Furthermore, omega-3 fatty-acid supplementation has been reported to be useful for depressive symptoms in PD (da Silva et al., 2008).

Deep brain stimulation with subthalamic nucleus (STN) or internal globus pallidus (GPi) stimulation showed a short-term improvement in depression (mainly class I and II data) and anxiety (class I data) with a waning in effect over the longer term(Couto et al., 2014). Differences between both targets could not be elucidated.

In conclusion, depression and anxiety is integral to PD and can occur as part of the disease process or non-motor fluctuations. Management therefore needs to address the underlying cause, however, robust evidence based for good anti-depressants antianxiolytics including NSRIs, SSRIs TCA, dopamine agonists and other agents is still lacking. At this moment in time, current data does not indicate towards one specific class of antidepressants when compared with a placebo.

\section{Autonomic}

\section{Orthostatic hypotension}

Orthostatic hypotension $(\mathrm{OH})$ is a clinical sign defined by a drop of systolic blood pressure (SBP) of at least $20 \mathrm{mmHg}$ or diastolic blood pressure of at least $10 \mathrm{mmHg}$ 
within 3 minutes after assuming a standing position. It may be asymptomatic or accompanied with orthostatic symptoms such as dizziness, lightheadedness, or syncope (Freeman et al., 2011). Prevalence of OH in PD is estimated to be around 3040\% (Velseboer et al., 2011). OH prevalence increases with disease duration (Rocchi et al., 2015) and might be worsened by dopaminergic therapy in which case a dose reduction in refractory cases should be considered (Park and Stacy, 2011). The management of neurogenic $\mathrm{OH}(\mathrm{nOH})$ in $\mathrm{PD}$ is complex and requires patient education to optimally control symptoms that have functional impact on activities of daily living. Recommended practical values are a standing SBP $\geq 90 \mathrm{mmHg}$ and a supine SBP $\leq 180 \mathrm{mmHg}$ (Low and Tomalia, 2015).

Non-pharmacological therapies are first line interventions. Increased salt intake, increased water intake, and compression stockings ameliorate orthostatic symptoms (Wu and Hohler, 2015). Drinking caffeine-rich beverages, practice regular exercise, and avoiding warm weather and hot baths might provide some benefit as well for some patients (Figuerosa et al., 2010, Sanchez-Ferro et al., 2013) There is an increasing number of pharmacological therapies available and these are often administered in conjunction with non-pharmacologic interventions. Fludrocortisone, midodrine, droxidopa, domperidone, pyridostigmine and yohimbine have been used with different profiles of efficacy, mechanisms of action and side effects (Wu and Hohler, 2015). Domperidone might help OH, however owing to cardiovascular risks this cannot be routinely recommended. Furthermore, drugs therapies vary between countries.

Droxidopa (L-threo-dihydroxyphenylserine, L-DOPS) is a synthetic catechol-amino acid that is converted to norepinephrine by the enzyme dopa-decarboxylase. 
Droxidopa has been approved by the Food and Drug Administration (FDA) in the US for use in neurogenic $\mathrm{OH}(\mathrm{nOH})$ in PD since 2014, partly based on results from several studies including multicenter double-blind randomized placebo-controlled studies(Kaufmann et al., 2014, Biaggioni et al., 2015, Hauser et al., 2015). However, not all studies confirmed the beneficial effect of droxidopa and further investigations are needed (Schrag et al., 2015).

Only a few studies assessed the effect of DBS on autonomous symptoms including $\mathrm{OH}$ problems in PD patients. In a small study involving 14 PD patients, a decrease in blood pressure could be observed in the 'off' compared to the 'on' state, suggesting a positive influence of bilateral subthalamic nucleus stimulation on blood pressure (Stemper et al., 2006) and the positive effect on orthostatic hypotension was confirmed by other groups (Kurtis et al, 2017).

In contrast, other studies could not find major effects of DBS on cardiovascular autonomic nervous system functions (Ludwig et al., 2007, Lipp et al., 2005, Erola et al., 2006). Whether this potential positive effect is secondary to the reduction of oral medication after surgery or is a direct result of stimulating central pathways, remains to be clarified and needs further investigation.

In summary, $\mathrm{OH}$ occurs more commonly in $\mathrm{PD}$ than initially realized and recently droxidopa therapy has been shown to be effective, although not all research has confirmed this. While conventional and supportive therapies are effective, large scale control studies with new investigational products are required.

\section{Urinary dysfunction}


Lower urinary tract symptoms (LUTS) and dysfunction are commonly reported to play a key role in the quality of life of PD patients, however randomized clinical trials addressing urinary dysfunction are currently lacking. LUTS are composed of two major categories: storage symptoms (e.g. urgency, frequency, nocturia, and incontinence) and voiding symptoms (e.g. hesitancy, interrupted or poor stream, and double voiding), and both are reported to occur in PD (Sakakibara et al., 2014). Storage symptoms are thought to be related to detrusor overactivity and voiding symptoms may result from bladder hypoactivity or an obstruction in the lower urinary tract. However, nocturia is one of the most reported symptoms followed by frequency (McDonald et al., 2016).

When addressing urinary dysfunction, it is important to establish if the symptoms are related to fluctuations in which case adjustment of dopaminergic medication can be considered. However, the role of dopaminergic medication in the management of LUTS is unclear, with most studies using urodynamic studies to date showing conflicting results (McDonald et al., 2016, Sakakibara et al., 2016). At the same time, even though most bladder dysfunction is related to PD itself, it is important to check for common bladder diseases as recently summarized by Sakakibara et al (Sakakibara et al., 2016). Male and female patients over 50 years-old should be investigated for benign prostatic enlargement and stress-induced urinary incontinence, respectively (Sakakibara et al., 2016).

Anti-muscarinics are used routinely in clinical practice to treat overactive bladder with Oxybutynin being the most investigated one.

Solifenacine, darfenacin and trospium were approved by the FDA together with two further antimuscarinic agents darfenacin and trospium in 2004 for its use in overactive 
bladder (Hesch, 2007). A recent study by the Parkinson Study Group with a randomized, placebo-controlled 3-site setting measuring the mean number of micturitions per $24 \mathrm{~h}$ as a primary outcome, showed no significant improvement among the treated group, but showed a significant reduction in the number of incontinence and nocturia episodes (Zesiewicz et al., 2015). Furthermore, Propiverine and Tolterodine were studied (Sakakibara et al., 2016). Intravesical botulinum toxin injections have been reported to be successful in treating hyperactive bladder dysfunction (Kulaksizoglu and Parman, 2010; Giannantoni et al., 2011)

Newer treatment options currently being investigated for bladder dysfunction include; a beta-3 adrenergic agonist such as Mirabegron, DBS, as well as posterior tibial nerve stimulation (PTNS)(Schrag et al., 2015) (Sakakibara et al., 2016).

In conclusion, urinary dysfunction may complicate PD from an early stage and might even be a prodromal sign. Management of urinary dysfunction remains a key unmet need although recent clinical trials with Solifenacine seem promising.

\section{Gastrointestinal dysfunction}

Gastrointestinal dysfunction plays a key role in PD with constipation being the most common symptom (Rossi et al., 2015). In the literature, constipation is characterized as less than three bowel movements a week or having to strain to pass a stool (Chaudhuri et al., 2006b). Limited data is published on the management of constipation in PD patients. In the literature constipation in PD is sometimes divided 
into two types; constipation due to slow colonic transit and/or constipation due to defecatory dysfunction, which is often related to pelvic floor dyssynergia (Rossi et al., 2015).

In relation to the first form of constipation, after exclusion of secondary causes, lifestyle changes are among the first-line recommendation as they can have a significant positive impact. These include an increase in the amount of fibre and water intake as well as physical activity (Barboza et al., 2015, Rossi et al., 2015). In case these non-pharmacological strategies are not successful, bulk forming laxatives such as psyllium and osmotic laxatives including polyethylene glycol (PEG, macrogol) have been shown useful to treat constipation. as Additionally, the FDA approved chloride channel activator called lubiprostine and similarly the guanylate cyclase C receptor peptide called linaclotide have shown useful to treat constipation. Also, the serotonin 5-HT4 receptor agonist mosaprode has been studied alongside elobixibat and ileal sodium/bile acid co-transoprter (Barboza et al., 2015).

On the other hand, levodopa or apomorphine injection, botulinum toxin injections into the puborectalis muscle, and non-pharmacological interventions, like biofeedback therapy or functional magnetic stimulation have been reported to improve the defecatory dysfunction related constipation (Rossi et al., 2015). Another development has addressed the effect of ghrelin receptor agonist (HM01) in rats, in vitro as well as in vivo and found promising results, however, these need further investigation (Karasawa et al., 2014).

In conclusion, gastrointestinal dysfunction are common non-motor features in PD with constipation being the most frequent one. Exclusion of secondary causes is important and non-pharmacological treatment strategies can often offer a considerable 
improvement. Several pharmacological treatments such as laxatives are routinely used in clinical practice while new drugs are currently under development.

\section{The possible role of nutrition and Parkinson's disease}

While historically relegated to the symptomatic management of dysphagia, constipation and interactions between dietary protein and levodopa, it is now evident the topic of nutrition in PD is more complex than once thought. Epidemiological studies suggests coffee, tea, dark berries, a plant-based diet and dairy avoidance decrease PD incidence (Qi and Li, 2014, Gao et al., 2012, Jiang et al., 2014, Gao et al., 2007), and studies are underway to evaluate whether these variables are associated with PD progression (Mischley LK, 2015). Early involvement of the gastrointestinal tract is supported by the finding that constipation and $\alpha$-synuclein aggregation are observed in the salivary glands and intestinal mucosa over a decade prior to the onset of PD motor symptoms (Adams-Carr et al., 2016, Mukherjee et al., 2016). Recently, of alterations in the intestinal microbiome have been described (Scheperjans, 2016) and a dietary Lactobacillus supplement was shown to improve bowel health (Cassani et al., 2011). Beyond diet, perturbations in essential metabolites have also been demonstrated in PD; patients are more likely be deficient in glutathione (Zeevalk et al., 2008), coenzyme Q10 (Mischley et al., 2012), lithium (Mischley, 2013), and folic acid, the latter attributable to a levodopa side effect (Paul and Borah, 2016). Not all drug-nutrient interactions are negative, as several studies suggest cytidine diphosphate choline has a levodopa-sparing effect (Cubells and Hernando, 1988). It is unclear whether a subset of PD symptoms are manifestations of nutritional deficiency symptoms or whether depletion of nutrients is associated with disease progression 
(Mischley, 2014). To date, no guidelines exist for the screening, evaluation, and management of nutrition in PD.

\section{Non-motor subtype specific treatment in Parkinson's disease?}

NMS are a major determinant of quality of life and caregiver stress. In spite the evidence based for treatment on NMS, in particular level I evidence remains scare. Most clinical trials still focus dominantly on the motor symptoms in spite of the availability of holistic NM measurements. However, the recognition of specific NMS subtypes is likely to generate trials focused on subtype specific medicine and more individualized treatment in future. Such strategy will enhance the quality of life of many PD patients with the high non-motor burden in future. 


\section{References}

AARSLAND, D. \& KRAMBERGER, M. G. 2015. Neuropsychiatric symptoms in Parkinson's disease. Journal of Parkinson's Disease, 5, 659-667.

ADAMS-CARR, K. L., BESTWICK, J. P., SHRIBMAN, S., LEES, A., SCHRAG, A. \& NOYCE, A. J. 2016. Constipation preceding Parkinson's disease: a systematic review and meta-analysis. J Neurol Neurosurg Psychiatry, 87, 710-6.

ARMENTO, M. E., STANLEY, M. A., MARSH, L., KUNIK, M. E., YORK, M. K., BUSH, A. L. \& CALLEO, J. S. 2012. Cognitive behavioral therapy for depression and anxiety in Parkinson's disease: a clinical review. J Parkinsons Dis, 2, 13551.

AURORA, R. N., ZAK, R. S., MAGANTI, R. K., AUERBACH, S. H., CASEY, K. R., CHOWDHURI, S., KARIPPOT, A., RAMAR, K., KRISTO, D. A. \& MORGENTHALER, T. I. 2010. Best practice guide for the treatment of REM sleep behavior disorder (RBD). J Clin Sleep Med, 6, 85-95.

BARBOZA, J. L., OKUN, M. S. \& MOSHIREE, B. 2015. The treatment of gastroparesis, constipation and small intestinal bacterial overgrowth syndrome in patients with Parkinson's disease. Expert Opin Pharmacother, 16, 2449-64.

BARONE, P., POEWE, W., ALBRECHT, S., DEBIEUVRE, C., MASSEY, D., RASCOL, O., TOLOSA, E. \& WEINTRAUB, D. 2010. Pramipexole for the treatment of depressive symptoms in patients with Parkinson's disease: a randomised, double-blind, placebo-controlled trial. Lancet Neurol, 9, 573-80.

BARONE, P., SANTANGELO, G., MORGANTE, L., ONOFRJ, M., MECO, G., ABBRUZZESE, G., BONUCCELLI, U., COSSU, G., PEZZOLI, G., STANZIONE, P., LOPIANO, L., ANTONINI, A. \& TINAZZI, M. 2015. A randomized clinical trial to evaluate the effects of rasagiline on depressive symptoms in nondemented Parkinson's disease patients. European Journal of Neurology, 22, 1184-1191.

BIAGGIONI, I., FREEMAN, R., MATHIAS, C. J., LOW, P., HEWITT, L. A. \& KAUFMANN, H. 2015. Randomized withdrawal study of patients with symptomatic neurogenic orthostatic hypotension responsive to droxidopa. Hypertension, 65, 101-7.

BOMASANG-LAYNO, E., FADLON, I., MURRAY, A. N. \& HIMELHOCH, S. 2015. Antidepressive treatments for Parkinson's disease: A systematic review and meta-analysis. Parkinsonism Relat Disord, 21, 833-42; discussion 833.

BORISOVSKAYA, A., BRYSON, W. C., BUCHHOLZ, J., SAMII, A. \& BORSON, S. 2016. Electroconvulsive therapy for depression in Parkinson's disease: systematic review of evidence and recommendations. Neurodegener Dis Manag, 6, 161-76.

BROEDERS, M., DE BIE, R. M., VELSEBOER, D. C., SPEELMAN, J. D., MUSLIMOVIC, D. \& SCHMAND, B. 2013. Evolution of mild cognitive impairment in Parkinson disease. Neurology, 81, 346-52.

BROEN, M. P., NARAYEN, N. E., KUIJF, M. L., DISSANAYAKA, N. N. \& LEENTJENS, A. F. 2016. Prevalence of anxiety in Parkinson's disease: A systematic review and meta-analysis. Mov Disord, 31, 1125-33. 
BUCHWALD, B., ANGERSBACH, D. \& JOST, W. H. 2007. [Improvements in motor and non-motor symptoms in parkinson patients under ropinirole therapy]. Fortschr Neurol Psychiatr, 75, 236-41.

CALANDRA-BUONAURA, G., GUARALDI, P., DORIA, A., ZANIGNI, S., NASSETTI, S., FAVONI, V., CEVOLI, S., PROVINI, F. \& CORTELLI, P. 2016. Rotigotine Objectively Improves Sleep in Parkinson's Disease: An Open-Label Pilot Study with Actigraphic Recording. Parkinsons Dis, 2016, 3724148.

CASSANI, E., PRIVITERA, G., PEZZOLI, G., PUSANI, C., MADIO, C., IORIO, L. \& BARICHELLA, M. 2011. Use of probiotics for the treatment of constipation in Parkinson's disease patients. Minerva Gastroenterol Dietol, 57, 117-21.

CHAHINE, L. M., AMARA, A. W. \& VIDENOVIC, A. 2016. A systematic review of the literature on disorders of sleep and wakefulness in Parkinson's disease from 2005 to 2015. Sleep Med Rev.

CHAUDHURI, K. R., HEALY, D. G. \& SCHAPIRA, A. H. 2006a. Non-motor symptoms of Parkinson's disease: diagnosis and management. Lancet Neurol, 5, 23545.

CHAUDHURI, K. R., MARTINEZ-MARTIN, P., BROWN, R. G., SETHI, K., STOCCHI, F., ODIN, P., ONDO, W., ABE, K., MACPHEE, G., MACMAHON, D., BARONE, P., RABEY, M., FORBES, A., BREEN, K., TLUK, S., NAIDU, Y., OLANOW, W., WILLIAMS, A. J., THOMAS, S., RYE, D., TSUBOI, Y., HAND, A. \& SCHAPIRA, A. H. 2007. The metric properties of a novel non-motor symptoms scale for Parkinson's disease: Results from an international pilot study. Mov Disord, 22, 1901-11.

CHAUDHURI, K. R., MARTINEZ-MARTIN, P., SCHAPIRA, A. H., STOCCHI, F., SETHI, K., ODIN, P., BROWN, R. G., KOLLER, W., BARONE, P., MACPHEE, G., KELLY, L., RABEY, M., MACMAHON, D., THOMAS, S., ONDO, W., RYE, D., FORBES, A., TLUK, S., DHAWAN, V., BOWRON, A., WILLIAMS, A. J. \& OLANOW, C. W. 2006b. International multicenter pilot study of the first comprehensive self-completed nonmotor symptoms questionnaire for Parkinson's disease: the NMSQuest study. Mov Disord, 21, 916-23.

CHAUDHURI, K. R. \& SAUERBIER, A. 2016. Parkinson disease. Unravelling the nonmotor mysteries of Parkinson disease. Nat Rev Neurol, 12, 10-1.

COUTO, M. I., MONTEIRO, A., OLIVEIRA, A., LUNET, N. \& MASSANO, J. 2014. Depression and anxiety following deep brain stimulation in Parkinson's disease: systematic review and meta-analysis. Acta Med Port, 27, 372-82.

CUBELLS, J. M. \& HERNANDO, C. 1988. Clinical trial on the use of cytidine diphosphate choline in Parkinson's disease. Clin Ther, 10, 664-71.

CUSSO, M. E., DONALD, K. J. \& KHOO, T. K. 2016. The Impact of Physical Activity on Non-Motor Symptoms in Parkinson's Disease: A Systematic Review. Front Med (Lausanne), 3, 35.

DA SILVA, T. M., MUNHOZ, R. P., ALVAREZ, C., NALIWAIKO, K., KISS, A., ANDREATINI, R. \& FERRAZ, A. C. 2008. Depression in Parkinson's disease: a double-blind, randomized, placebo-controlled pilot study of omega-3 fatty-acid supplementation. J Affect Disord, 111, 351-9.

DAFSARI, H. S., REDDY, P., HERCHENBACH, C., WAWRO, S., PETRY-SCHMELZER, J. N., VISSER-VANDEWALLE, V., RIZOS, A., SILVERDALE, M., ASHKAN, K., SAMUEL, M., EVANS, J., HUBER, C. A., FINK, G. R., ANTONINI, A., CHAUDHURI, K. R., MARTINEZ-MARTIN, P. \& TIMMERMANN, L. 2016. 
Beneficial Effects of Bilateral Subthalamic Stimulation on Non-Motor Symptoms in Parkinson's Disease. Brain Stimul, 9, 78-85.

DI GIACOPO, R., FASANO, A., QUARANTA, D., DELLA MARCA, G., BOVE, F. \& BENTIVOGLIO, A. R. 2012. Rivastigmine as alternative treatment for refractory REM behavior disorder in Parkinson's disease. Mov Disord, 27, 559-61.

DOWLING, G. A., MASTICK, J., COLLING, E., CARTER, J. H., SINGER, C. M. \& AMINOFF, M. J. 2005. Melatonin for sleep disturbances in Parkinson's disease. Sleep Med, 6, 459-66.

EROLA, T., HAAPANIEMI, T., HEIKKINEN, E., HUIKURI, H. \& MYLLYA, V. 2006. Subthalamic nucleus deep brain stimulation does not alter long-term heart rate variability in Parkinson's disease. Clin Auton Res, 16, 286-8.

EUGSTER, L., BARGIOTAS, P., BASSETTI, C. L. \& MICHAEL SCHUEPBACH, W. M. 2016. Deep brain stimulation and sleep-wake functions in Parkinson's disease: A systematic review. Parkinsonism Relat Disord, 32, 12-19.

Figueroa, JJ., Basford, FR. \& Low, PA. Preventing and treating orthostatic hypotension: As easy as A, B, C. Cleve Clin J Med. 2010;77:298-306.

FRAZZITTA, G., MAESTRI, R., FERRAZZOLI, D., RIBOLDAZZI, G., BERA, R., FONTANESI, C., ROSSI, R. P., PEZZOLI, G. \& GHILARDI, M. F. 2015. Multidisciplinary intensive rehabilitation treatment improves sleep quality in Parkinson's disease. J Clin Mov Disord, 2, 11.

FREEMAN, R., WIELING, W., AXELROD, F. B., BENDITT, D. G., BENARROCH, E., BIAGGIONI, I., CHESHIRE, W. P., CHELIMSKY, T., CORTELLI, P., GIBBONS, C. H., GOLDSTEIN, D. S., HAINSWORTH, R., HILZ, M. J., JACOB, G., KAUFMANN, H., JORDAN, J., LIPSITZ, L. A., LEVINE, B. D., LOW, P. A., MATHIAS, C., RAJ, S. R., ROBERTSON, D., SANDRONI, P., SCHATZ, I., SCHONDORFF, R., STEWART, J. M. \& VAN DIJK, J. G. 2011. Consensus statement on the definition of orthostatic hypotension, neurally mediated syncope and the postural tachycardia syndrome. Clin Auton Res, 21, 6972.

GAO, X., CASSIDY, A., SCHWARZSCHILD, M. A., RIMM, E. B. \& ASCHERIO, A. 2012. Habitual intake of dietary flavonoids and risk of Parkinson disease. Neurology, 78, 1138-45.

GAO, X., CHEN, H., FUNG, T. T., LOGROSCINO, G., SCHWARZSCHILD, M. A., HU, F. B. \& ASCHERIO, A. 2007. Prospective study of dietary pattern and risk of Parkinson disease. Am J Clin Nutr, 86, 1486-94.

GIANNANTONI, A., CONTE, A., PROIETTI, S., GIOVANNOZZI, S., ROSSI, A., FABBRINI, G., PORENA, M. \& BERARDELLI, A. 2011. Botulinum toxin type A in patients with Parkinson's disease and refractory overactive bladder. $J$ Urol, 186, 960-4.

GOETZ, C. G., TILLEY, B. C., SHAFTMAN, S. R., STEBBINS, G. T., FAHN, S., MARTINEZ-MARTIN, P., POEWE, W., SAMPAIO, C., STERN, M. B., DODEL, R., DUBOIS, B., HOLLOWAY, R., JANKOVIC, J., KULISEVSKY, J., LANG, A. E., LEES, A., LEURGANS, S., LEWITT, P. A., NYENHUIS, D., OLANOW, C. W., RASCOL, O., SCHRAG, A., TERESI, J. A., VAN HILTEN, J. J. \& LAPELLE, N. 2008. Movement Disorder Society-sponsored revision of the Unified 
Parkinson's Disease Rating Scale (MDS-UPDRS): scale presentation and clinimetric testing results. Mov Disord, 23, 2129-70.

GOODARZI, Z., MRKLAS, K. J., ROBERTS, D. J., JETTE, N., PRINGSHEIM, T. \& HOLROYD-LEDUC, J. 2016. Detecting depression in Parkinson disease: A systematic review and meta-analysis. Neurology, 87, 426-437.

HAGELL, P. \& BROMAN, J. E. 2007. Measurement properties and hierarchical item structure of the Epworth Sleepiness Scale in Parkinson's disease. J Sleep Res, 16, 102-9.

HAUSER, R. A., ISAACSON, S., LISK, J. P., HEWITT, L. A. \& ROWSE, G. 2015. Droxidopa for the short-term treatment of symptomatic neurogenic orthostatic hypotension in Parkinson's disease (nOH306B). Mov Disord, 30, 646-54.

HESCH, K. 2007. Agents for treatment of overactive bladder: a therapeutic class review. Proc (Bayl Univ Med Cent), 20, 307-14.

JIANG, W., JU, C., JIANG, H. \& ZHANG, D. 2014. Dairy foods intake and risk of Parkinson's disease: a dose-response meta-analysis of prospective cohort studies. Eur J Epidemiol, 29, 613-9.

JOHNS, M. W. 1991. A new method for measuring daytime sleepiness: the Epworth sleepiness scale. Sleep, 14, 540-5.

KARASAWA, H., PIETRA, C., GIULIANO, C., GARCIA-RUBIO, S., XU, X., YAKABI, S., TACHE, Y. \& WANG, L. 2014. New ghrelin agonist, HM01 alleviates constipation and L-dopa-delayed gastric emptying in 6-hydroxydopamine rat model of Parkinson's disease. Neurogastroenterol Motil, 26, 1771-82.

KAUFMANN, H., FREEMAN, R., BIAGGIONI, I., LOW, P., PEDDER, S., HEWITT, L. A., MAUNEY, J., FEIRTAG, M. \& MATHIAS, C. J. 2014. Droxidopa for neurogenic orthostatic hypotension: a randomized, placebo-controlled, phase 3 trial. Neurology, 83, 328-35.

KULAKSIZOGLU, H. \& PARMAN, Y. 2010. Use of botulinim toxin-A for the treatment of overactive bladder symptoms in patients with Parkinsons's disease. Parkinsonism Relat Disord, 16, 531-4.

Kurtis, MM., Rajah, T., Delgado, LF. \& Dafsari, HS. 2017. The effect of deep brain stimulation on the non-motor symptoms of Parkinson's disease: a critical review of the current evidence npj Parkinson's Disease, 3, 16024

LIPP, A., TANK, J., TROTTENBERG, T., KUPSCH, A., ARNOLD, G. \& JORDAN, J. 2005. Sympathetic activation due to deep brain stimulation in the region of the STN. Neurology, 65, 774-5.

LOW, P. A. \& TOMALIA, V. A. 2015. Orthostatic Hypotension: Mechanisms, Causes, Management. J Clin Neurol, 11, 220-6.

LUDWIG, J., REMIEN, P., GUBALLA, C., BINDER, A., BINDER, S., SCHATTSCHNEIDER, J., HERZOG, J., VOLKMANN, J., DEUSCHL, G., WASNER, G. \& BARON, R. 2007. Effects of subthalamic nucleus stimulation and levodopa on the autonomic nervous system in Parkinson's disease. J Neurol Neurosurg Psychiatry, 78, 742-5.

MANENTI, R., BRAMBILLA, M., BENUSSI, A., ROSINI, S., COBELLI, C., FERRARI, C., PETESI, M., ORIZIO, I., PADOVANI, A., BORRONI, B. \& COTELLI, M. 2016. Mild cognitive impairment in Parkinson's disease is improved by 
transcranial direct current stimulation combined with physical therapy. Mov Disord, 31, 715-24.

MARCO, A. D., APPIAH-KUBI, L. S. \& CHAUDHURI, K. R. 2002. Use of the dopamine agonist cabergoline in the treatment of movement disorders. Expert Opinion on Pharmacotherapy, 3, 1481-7.

Marras, C. \& Chaudhuri KR 2016. Nonmotor features of Parkinson's disease subtypes.Mov Disord., 31, 1095-102.

MARSH, L., BIGLAN, K., GERSTENHABER, M. \& WILLIAMS, J. R. 2009. Atomoxetine for the treatment of executive dysfunction in Parkinson's disease: a pilot open-label study. Mov Disord, 24, 277-82.

MARTINEZ-MARTIN, P. 2014. Nonmotor symptoms and health-related quality of life in early Parkinson's disease. Mov Disord, 29, 166-8.

MARTINEZ-MARTIN, P., REDDY, P., ANTONINI, A., HENRIKSEN, T., KATZENSCHLAGER, R., ODIN, P., TODOROVA, A., NAIDU, Y., TLUK, S., CHANDIRAMANI, C., MARTIN, A. \& CHAUDHURI, K. R. 2011. Chronic subcutaneous infusion therapy with apomorphine in advanced Parkinson's disease compared to conventional therapy: a real life study of non motor effect. J Parkinsons Dis, 1, 197-203.

MARTINEZ-MARTIN, P., REDDY, P., KATZENSCHLAGER, R., ANTONINI, A., TODOROVA, A., ODIN, P., HENRIKSEN, T., MARTIN, A., CALANDRELLA, D., RIZOS, A., BRYNDUM, N., GLAD, A., DAFSARI, H. S., TIMMERMANN, L., EBERSBACH, G., KRAMBERGER, M. G., SAMUEL, M., WENZEL, K., TOMANTSCHGER, V., STORCH, A., REICHMANN, H., PIRTOSEK, Z., TROST, M., SVENNINGSSON, P., PALHAGEN, S., VOLKMANN, J. \& CHAUDHURI, K. R. 2015. EuroInf: AMulticenter Comparative Observational Study of Apomorphine and Levodopa Infusion in Parkinson's Disease. Movement Disorders, 30, 510-516.

MCDONALD, C., WINGE, K. \& BURN, D. J. 2016. Lower urinary tract symptoms in Parkinson's disease: Prevalence, aetiology and management. Parkinsonism Relat Disord.

MERLINO, G., LETTIERI, C., MONDANI, M., BELGRADO, E., DEVIGILI, G., MUCCHIUT, M., RINALDO, S., CRAIGHERO, C., D'AURIA, S., SKRAP, M. \& ELEOPRA, R. 2014. Microsubthalamotomy improves sleep in patients affected by advanced Parkinson's disease. Sleep Med, 15, 637-41.

MISCHLEY, L. K. 2013. Lithium Deficiency in Parkinson's Disease. Master of Public Health, University of Washington.

MISCHLEY, L. K. 2014. Conditionally Essential Nutrients: The State of the Science. Journal of Food and Nutrition, 1, 1-4.

MISCHLEY LK 2015. Complementary \& Alternative Medicine in Parkinson's Disease (CAM Care in PD). ClinicalTrials.gov. U.S. Natiional Institutes of Health.

MISCHLEY, L. K., ALLEN, J. \& BRADLEY, R. 2012. Coenzyme Q10 deficiency in patients with Parkinson's disease. J Neurol Sci, 318, 72-5.

MOELLENTINE, C., RUMMANS, T., AHLSKOG, J. E., HARMSEN, W. S., SUMAN, V. J., O'CONNOR, M. K., BLACK, J. L. \& PILEGGI, T. 1998. Effectiveness of ECT in patients with parkinsonism. J Neuropsychiatry Clin Neurosci, 10, 187-93.

MUKHERJEE, A., BISWAS, A. \& DAS, S. K. 2016. Gut dysfunction in Parkinson's disease. World J Gastroenterol, 22, 5742-52. 
NARANG, P., GLOWACKI, A. \& LIPPMAN, S. 2015. Electroconvulsive therapy intervention for Parkinson's disease. Innovations in Clinical Neuroscience, 12, 25-28.

NEIKRUG, A. B., LIU, L., AVANZINO, J. A., MAGLIONE, J. E., NATARAJAN, L., BRADLEY, L., MAUGERI, A., COREY-BLOOM, J., PALMER, B. W., LOREDO, J. S. \& ANCOLI-ISRAEL, S. 2014. Continuous positive airway pressure improves sleep and daytime sleepiness in patients with Parkinson disease and sleep apnea. Sleep, 37, 177-85.

ONDO, W. G., PERKINS, T., SWICK, T., HULL, K. L., JR., JIMENEZ, J. E., GARRIS, T. S. \& PARDI, D. 2008. Sodium oxybate for excessive daytime sleepiness in Parkinson disease: an open-label polysomnographic study. Arch Neurol, 65, 1337-40.

PAGONABARRAGA, J., PINOL, G., CARDOZO, A., SANZ, P., PUENTE, V., OTERMIN, P., LEGARDA, I., DELGADO, T., SERRANO, C., BALAGUER, E., AGUIRREGOMOZCORTA, M., ALVAREZ, R. \& KULISEVSKY, J. J. 2015. Transdermal Rotigotine Improves Sleep Fragmentation in Parkinson's Disease: Results of the Multicenter, Prospective SLEEP-FRAM Study. Parkinsons Dis, 2015, 131508.

PANISSET, M., STRIL, J. L., BELANGER, M., LEHOUX, G., COFFIN, D. \& CHOUINARD, S. 2016. Open-Label Study of Sleep Disturbances in Patients with Parkinson's Disease Treated with Rasagiline. Can J Neurol Sci, 43, 809814.

PARK, A. \& STACY, M. 2011. Dopamine-induced nonmotor symptoms of Parkinson's disease. Parkinsons Dis, 2011, 485063.

PAUL, R. \& BORAH, A. 2016. L-DOPA-induced hyperhomocysteinemia in Parkinson's disease: Elephant in the room. Biochim Biophys Acta, 1860, 1989-97.

PENA, E., MATA, M., LOPEZ-MANZANARES, L., KURTIS, M., EIMIL, M., MARTINEZCASTRILLO, J. C., NAVAS, I., POSADA, I. J., PRIETO, C., RUIZ-HUETE, C., VELA, L. \& VENEGAS, B. 2016. Antidepressants in Parkinson's disease. Recommendations by the movement disorder study group of the Neurological Association of Madrid. Neurologia.

PIERANTOZZI, M., PLACIDI, F., LIGUORI, C., ALBANESE, M., IMBRIANI, P., MARCIANI, M. G., MERCURI, N. B., STANZIONE, P. \& STEFANI, A. 2016. Rotigotine may improve sleep architecture in Parkinson's disease: a double-blind, randomized, placebo-controlled polysomnographic study. Sleep Med, 21, 140-4.

POSTUMA, R. B., LANG, A. E., MUNHOZ, R. P., CHARLAND, K., PELLETIER, A., MOSCOVICH, M., FILLA, L., ZANATTA, D., RIOS ROMENETS, S., ALTMAN, R., CHUANG, R. \& SHAH, B. 2012. Caffeine for treatment of Parkinson disease: a randomized controlled trial. Neurology, 79, 651-8.

QI, H. \& LI, S. 2014. Dose-response meta-analysis on coffee, tea and caffeine consumption with risk of Parkinson's disease. Geriatr Gerontol Int, 14, 430-9.

REKTOROVA, I., BALAZ, M., SVATOVA, J., ZARUBOVA, K., HONIG, I., DOSTAL, V., SEDLACKOVA, S., NESTRASIL, I., MASTIK, J., BARES, M., VELISKOVA, J. \& DUSEK, L. 2008. Effects of ropinirole on nonmotor symptoms of Parkinson disease: a prospective multicenter study. Clin Neuropharmacol, 31, 261-6. 
RIOS ROMENETS, S., CRETI, L., FICHTEN, C., BAILES, S., LIBMAN, E., PELLETIER, A. \& POSTUMA, R. B. 2013. Doxepin and cognitive behavioural therapy for insomnia in patients with Parkinson's disease - A randomized study. Parkinsonism \& Related Disorders, 19, 670-675.

ROCCHI, C., PIERANTOZZI, M., GALATI, S., CHIARAVALLOTI, A., PISANI, V., PROSPERETTI, C., LAURETTI, B., STAMPANONI BASSI, M., OLIVOLA, E., SCHILLACI, O. \& STEFANI, A. 2015. Autonomic Function Tests and MIBG in Parkinson's Disease: Correlation to Disease Duration and Motor Symptoms. CNS Neurosci Ther, 21, 727-32.

RODRIGUES, T. M., CALDAS, A. C. \& FERREIRA, J. J. 2016. Pharmacological interventions for daytime sleepiness and sleep disorders in Parkinson's disease: Systematic review and meta-analysis. Parkinsonism \& Related Disorders, 27, 25-34.

ROMIGI, A., STANZIONE, P., MARCIANI, M. G., IZZI, F., PLACIDI, F., CERVELLINO, A., GIACOMINI, P., BRUSA, L., GROSSI, K. \& PIERANTOZZI, M. 2006. Effect of cabergoline added to levodopa treatment on sleep-wake cycle in idiopathic Parkinson's disease: an open label 24-hour polysomnographic study. J Neural Transm (Vienna), 113, 1909-13.

ROSSI, M., MERELLO, M. \& PEREZ-LLORET, S. 2015. Management of constipation in Parkinson's disease. Expert Opin Pharmacother, 16, 547-57.

RUTTEN, S., VRIEND, C., VAN DEN HEUVEL, O. A., SMIT, J. H., BERENDSE, H. W. \& VAN DER WERF, Y. D. 2012. Bright light therapy in Parkinson's disease: an overview of the background and evidence. Parkinsons Dis, 2012, 767105.

SAKAKIBARA, R., PANICKER, J., FINAZZI-AGRO, E., IACOVELLI, V. \& BRUSCHINI, H. 2016. A guideline for the management of bladder dysfunction in Parkinson's disease and other gait disorders. Neurourol Urodyn, 35, 55163.

SAKAKIBARA, R., TATENO, F., NAGAO, T., YAMAMOTO, T., UCHIYAMA, T., YAMANISHI, T., YANO, M., KISHI, M., TSUYUSAKI, Y. \& AIBA, Y. 2014. Bladder function of patients with Parkinson's disease. Int J Urol, 21, 63846.

Sánchez-Ferro, A., Benito-León, J. \& Gómez-Esteban, JC.

The management of orthostatic hypotension in Parkinson's disease. Front Neurol. 2013;4:64.

SAUERBIER, A., JENNER, P., TODOROVA, A. \& CHAUDHURI, K. 2016. Non motor subtypes and Parkinson's disease. Parkinsonism \& Related Disorders, 22, S41-S46.

SAUERBIER, A. \& RAY CHAUDHURI, K. 2014. Non-motor symptoms: the core of multi-morbid Parkinson's disease. Br J Hosp Med (Lond), 75, 18-24.

SCHEPERJANS, F. 2016. Gut microbiota, 1013 new pieces in the Parkinson's disease puzzle. Curr Opin Neurol, 29, 773-780.

SCHRAG, A., SAUERBIER, A. \& CHAUDHURI, K. R. 2015. New clinical trials for nonmotor manifestations of Parkinson's disease. Mov Disord, 30, 1490504.

SEPPI, K., WEINTRAUB, D., COELHO, M., PEREZ-LLORET, S., FOX, S. H., KATZENSCHLAGER, R., HAMETNER, E. M., POEWE, W., RASCOL, O., GOETZ, C. G. \& SAMPAIO, C. 2011. The Movement Disorder Society 
Evidence-Based Medicine Review Update: Treatments for the non-motor symptoms of Parkinson's disease. Mov Disord, 26 Suppl 3, S42-80.

SMITH, K. M., EYAL, E. \& WEINTRAUB, D. 2015. Combined rasagiline and antidepressant use in Parkinson disease in the ADAGIO study: effects on nonmotor symptoms and tolerability. JAMA Neurol, 72, 88-95.

STEMPER, B., BERIC, A., WELSCH, G., HAENDL, T., STERIO, D. \& HILZ, M. J. 2006. Deep brain stimulation improves orthostatic regulation of patients with Parkinson disease. Neurology, 67, 1781-5.

STROHLE, A., SCHMIDT, D. K., SCHULTZ, F., FRICKE, N., STADEN, T., HELLWEG, R., PRILLER, J., RAPP, M. A. \& RIECKMANN, N. 2015. Drug and Exercise Treatment of Alzheimer Disease and Mild Cognitive Impairment: A Systematic Review and Meta-Analysis of Effects on Cognition in Randomized Controlled Trials. Am J Geriatr Psychiatry, 23, 1234-49.

TRENKWALDER, C., KIES, B., RUDZINSKA, M., FINE, J., NIKL, J., HONCZARENKO, K., DIOSZEGHY, P., HILL, D., ANDERSON, T., MYLLYLA, V., KASSUBEK, J., STEIGER, M., ZUCCONI, M., TOLOSA, E., POEWE, W., SURMANN, E., WHITESIDES, J., BOROOJERDI, B. \& CHAUDHURI, K. R. 2011a. Rotigotine effects on early morning motor function and sleep in Parkinson's disease: a double-blind, randomized, placebo-controlled study (RECOVER). Mov Disord, 26, 90-9.

TRENKWALDER, C., KOHNEN, R., HOGL, B., METTA, V., SIXEL-DORING, F., FRAUSCHER, B., HULSMANN, J., MARTINEZ-MARTIN, P. \& CHAUDHURI, K. R. 2011b. Parkinson's disease sleep scale--validation of the revised version PDSS-2. Mov Disord, 26, 644-52.

VELSEBOER, D. C., DE HAAN, R. J., WIELING, W., GOLDSTEIN, D. S. \& DE BIE, R. M. 2011. Prevalence of orthostatic hypotension in Parkinson's disease: a systematic review and meta-analysis. Parkinsonism Relat Disord, 17, 7249.

WANG, H. F., YU, J. T., TANG, S. W., JIANG, T., TAN, C. C., MENG, X. F., WANG, C., TAN, M. S. \& TAN, L. 2015. Efficacy and safety of cholinesterase inhibitors and memantine in cognitive impairment in Parkinson's disease, Parkinson's disease dementia, and dementia with Lewy bodies: systematic review with meta-analysis and trial sequential analysis. $J$ Neurol Neurosurg Psychiatry, 86, 135-43.

WU, C. K. \& HOHLER, A. D. 2015. Management of orthostatic hypotension in patients with Parkinson's disease. Pract Neurol, 15, 100-4.

YANG, S., SAJATOVIC, M. \& WALTER, B. L. 2012. Psychosocial interventions for depression and anxiety in Parkinson's disease. J Geriatr Psychiatry Neurol, 25, 113-21.

ZEEVALK, G. D., RAZMPOUR, R. \& BERNARD, L. P. 2008. Glutathione and Parkinson's disease: is this the elephant in the room? Biomed Pharmacother, 62, 236-49.

ZESIEWICZ, T. A., EVATT, M., VAUGHAN, C. P., JAHAN, I., SINGER, C., ORDORICA, R., SALEMI, J. L., SHAW, J. D. \& SULLIVAN, K. L. 2015. Randomized, controlled pilot trial of solifenacin succinate for overactive bladder in Parkinson's disease. Parkinsonism Relat Disord, 21, 514-20.

ZIBETTI, M., RIZZONE, M., MEROLA, A., ANGRISANO, S., RIZZI, L., MONTANARO, E., CICOLIN, A. \& LOPIANO, L. 2013. Sleep improvement with 
levodopa/carbidopa intestinal gel infusion in Parkinson disease. Acta Neurol Scand, 127, e28-32. 